\title{
INVESTIGATING SCOUR DEPTH AROUND BRIDGE PIERS IN CURVED CHANNELS
}

\begin{abstract}
Local scour around bridge piers is one of the most common causes of bridge failures. Many researchers studied the scour around the piers of bridges in straight channels. However, there is little information about the scour at bridge pier in a curved channel. In this paper, scouring is studied in curved channel at 30 degrees. Various piers forms were investigated to study local scour in the middle of the channel. The experimental study was conducted in a glasswalled $8 \mathrm{~m}$ long rectangular flume (i.e. $30 \mathrm{~cm} \times 60 \mathrm{~cm}$ ). It encompasses three parts (i.e. the first and last part are $3 \mathrm{~m}$ long, $60 \mathrm{~cm}$ wide and $30 \mathrm{~cm}$ high, the third part, at its middle, is curved with angle 30 degrees on the horizontal, $2 \mathrm{~m}$ length. The experimental program was designed to test relative distance $(\mathrm{b} / \mathrm{B}=0.5$ ) under 5 discharges (i.e. 13.89, 19.41, 23.77, 28.04 and $30.641 / \mathrm{sec}$ ). An ultrasonic device was used to measure the water levels and depths as well as the scour length so as the depth. This is achieved to investigate the pier type and shape efficiency in reducing the scour depth. It was found that the best performance was achieved in the case, where the substrate was placed in the middle of the waterway and the inclination angle was equal to zero, where the hexagonal reduced the scour depth by $34 \%$,relative to the maximum depth of scour.
\end{abstract}

\section{INTRODUCTION}

Bridge structures are most important structures. If they crack or collapse major damage will be evident accordingly, many studies were conducted to determine the factors that affect these 
structures. It is worldwide known that pier scour "is the erosion of the streambed in the vicinity of the pier foundation due to complex vortex system". This system consists of a horseshoe vortex and wake vortices. There is little information about scour around piers.

This research provides scour depth experimental results for different pier shapes placed in a curved channel in order to apprehend the effect of curvature on scour depths.

Many bridges failed in many countries due to extreme scour around bridge piers and abutments during floods, Shirole and Holt (1991). Accordingly, foundation of a pier of a bridge in an erodible riverbed is quite expensive. This is attributed to the fact that it should provide the minimum anchorage length for the safety of the foundation. Therefore, failure of bridges due to scour results in economical loss and might result in losses of human life

Piers and abutments are integral part of a bridge structure that obstruct the natural river flow and result in local scouring around them. Local scour involves removal of material around piers and abutments. It is caused by an acceleration of flow around the bridge foundation. Local scour can be either clear-water or live-bed. Live-bed conditions occur when there is transport of bed material in the approach reach.

Clear-water conditions occur when there is no bed material transport. Live-bed local scour is cyclic in nature as it allows the scour hole to develop, (during the water rising stage), it refills during the falling stage. Clear-water scour is permanent as it does not allow a scour-hole refilling. Many researchers were involved in investigating the local scour around bridge piers in water ways, experimentally or numerically or theoretically. Many researchers investigated scour around bridge piers and abutments, among them, for example are: van Rijn, Leo C. (1993) Venkatadri, C. (1965), White W. R. (1973), Sheppard, D. M. (2004), Sheppard, D. Max, MufeedOdeh and Tom Glasser (2002), (2004), Sheppard, D. Max, Jeffrey Sheldon, Eric Smith, and MufeedOdeh (2000), Sheppard, D. Max, MufeedOdeh, Tom Glasser, and Athanasios Pritsivelis (2000) and Sheppard, D. Max. (2000). all this studies have been done in straight channels.

In order to study local scour, $6 \mathrm{cmdiameter}$ pier was located in the straight channel and also in sections 30 and 60 degrees in the bend. This study estimated the minimum amount of scour depth "ds" for different discharges, when a pier is located in the bend.

Based on the present study results, the location of scour hole in the bend is close to the outer wall of channel and the point bar is close to the inner wall of channel.

The main feature of a bend flow is the presence of spiral flow and lateral sediment transport across the channel bend. Particles at the surface of the flow in the bend tend to move towards the outer wall while at the bed elevation they tend to move towards the inner wall of channel (Odgaard and Bergs, 1988).

This paper presents the experimental results on scour at a multi shapes pier located at different sections in a 30 degrees channel bend.

\section{RESEARCH OBJECTIVES}

This study was initiated in order to investigate the local scour around bridge piers. $60 \mathrm{~cm}$ wide and $800 \mathrm{~cm}$ long flume was implemented to investigate curved channel (flume). Also, among the research objectives were to determine the best shape that could offer the least scour depth (ds).

\section{THEORETICAL INVESTIGATION}

A theoretical study was conducted using numerical analysis method to detect the relationship between the various parameters and variables for all pier shapes; figure1. Functional relationships were obtained for the relative depth of the scour hole (ds/ds $)$ for the various shapes 

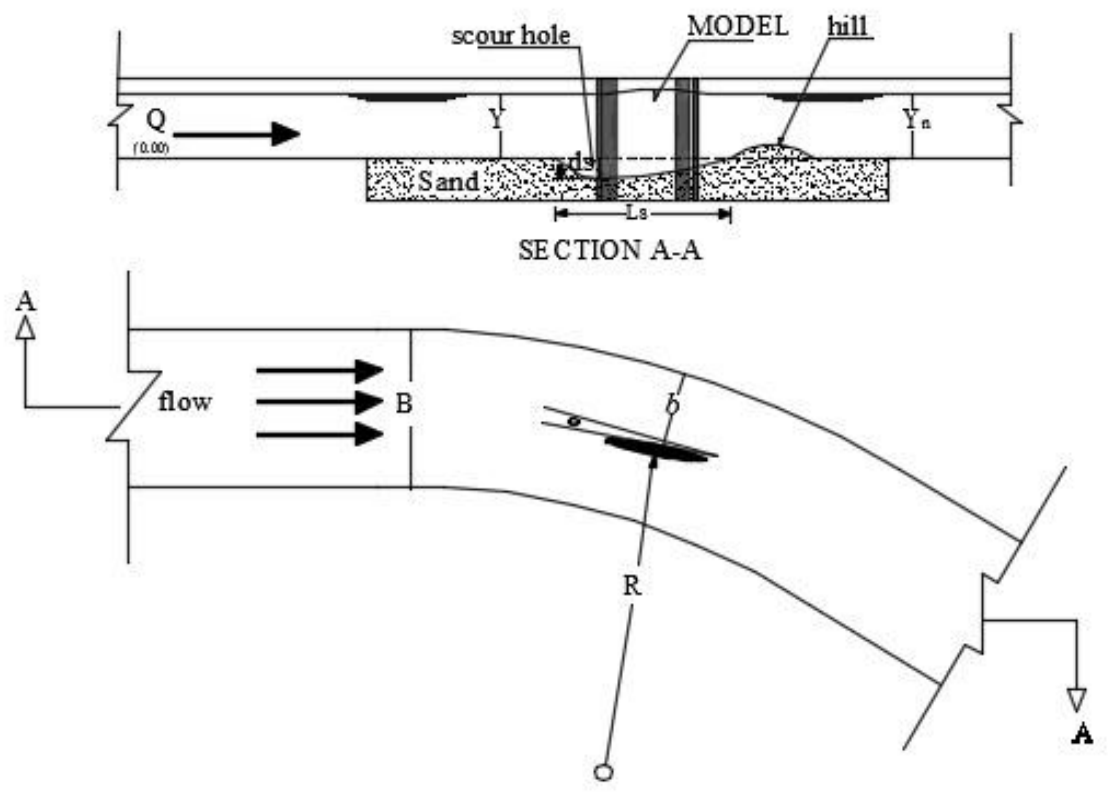

Fig.1 Definition sketch of all parameters.

The scour depth "ds" is the dependent variable .It can be expressed as a function of all other independent variables as follows.

ds : $\Phi\left(\mathrm{B}, \mathrm{b}, \mathrm{ds}_{\mathrm{m}}, \mathrm{T}, \mathrm{T}_{\mathrm{o}}, \mathrm{t}, \mathrm{Ls}, \quad \mathrm{Ls}_{\mathrm{m}}, \mathrm{y}, \mathrm{Q}, \quad \rho, \mathrm{g}, \mu, \quad \varnothing, \mathrm{D}_{50}, \mathrm{R}, \mathrm{S} . \mathrm{G}, \theta\right)$ ......................( 1 )

Regarding the boundary characteristics, they are, as follows:

B: Width of channel.

B: Distance from pier to the channel side

$\mathrm{R}$ : The radius of curvature

t: Thickness of piers

$\mathrm{g}$ : Gravitational acceleration

As for the flow characteristics, they are, as follows:

Q: Discharge.

Y: water depth

Focusing on the fluid characteristics, they are, as follows:

P: Mass density of fluid.

V: Kinematic viscosity.

g: Gravitational acceleration

T:Time interval

$\mathrm{T}_{\mathrm{O}}$ : Final time

Concerning the scour hole parameters, they are, as follows:

Ds: Maximum scour depth.

$\mathrm{L}_{\mathrm{S}}$ : Length of scour hole.

$\theta$ : Angle Tilt pier with the direction of flow

$\mathrm{ds}_{\mathrm{m}}$ : max scour depth

$\mathrm{Ls}_{\mathrm{m}}$ : max scour Length

As for the soil characteristics, they are, as follows:

S.G : Soil Specific gravity.

$\mathrm{D}_{50}$ : mean diameter of sediments.

Where:

Q: the discharge

$\rho$ : the density of fluid

$\mathrm{g}$ : the gravity acceleration

$\mu$ : the dynamic viscosity

S.G: the specific density

$\emptyset$ : the selected soil diameter 
$\mathrm{R}$ : The radius of curvature

Due to the fact that the implemented soil wasn't changed, parameters $\varnothing$ and S.G could be removed from the variables.

According to Buckingham $\pi$-theorem, ten variables ( $\pi$-terms and 2 repeated variables) are available.

These variables were arranged and the following non-dimensional $\pi$-terms were obtained

$$
\begin{array}{llll}
\pi_{1}=\mathrm{ds} / \mathrm{B} & \pi_{2}=\mathrm{b} / \mathrm{B} & \pi_{3}=\mathrm{ds}_{\mathrm{m}} / \mathrm{B} & \pi_{4}=\mathrm{Ls}_{\mathrm{m}} / \mathrm{B} \\
\pi_{5}=\mathrm{T} / \mathrm{T}_{\mathrm{O}} & \pi_{6}=\mathrm{L}_{\mathrm{S}} / \mathrm{B} & \pi_{7}=\mathrm{B} / \mathrm{Y} & \pi_{8}=\mathrm{QT} / \mathrm{B}^{3} \\
\pi_{9}=\mathrm{D}_{50} / \mathrm{B} & \pi_{10}=\mathrm{Q} 2 / \mathrm{B}^{5} \mathrm{~g} & &
\end{array}
$$

Taking the properties of $\boldsymbol{\pi}$-terms into account, the following relationship was obtained.

$$
\phi=\left(\frac{d s}{d s_{m}}, \frac{L s}{L s_{m}}, \frac{b}{B}, \frac{D_{50}}{R}, \frac{T}{T_{O}}, \frac{V}{\sqrt{g y}}, \theta\right)
$$

Where:

$\mathrm{ds} / \mathrm{ds}_{\mathrm{m}}$ is the relative scour depth

$\mathrm{Ls} / \mathrm{y}$ is the relative length of scour hole to be protected

$\mathrm{b} / \mathrm{B}$ is the, the contraction ratio

$\mathrm{QT} / \mathrm{y}^{2}$ is the time factor

$\mathrm{V} / \sqrt{\mathrm{gy}}$ is Fr the Froude number through the channel

Accordingly, the following functions were obtained:

$$
\frac{d s}{d s_{m}}=\phi\left(\frac{L s}{L s m}, \frac{b}{B}, \frac{T}{T_{O}}, F r\right)
$$

\section{EXPERIMENTAL WORK}

The experimental investigation has been conducted in an experimental flume at hydraulic laboratory of the faculty of engineering, Al- Azhar University, Cairo, Egypt (photo 1). The flume is $800 \mathrm{~cm}$ long, rectangular cross section steel frame of $60 \times 30 \mathrm{~cm}^{2}$ with visible clear polycarbonate sides to allow visual observation of the water surface. The flume layout is presented in details as shown in fig. 2.

The physical model (pier) is made from Polly carbonate. Four models shaped are suggested as traditional pier for this study. The test program was developed to deal with the pier shape as a mitigation technique against local scour, with a major focus on the time required to achieve an equilibrium scour condition. The test program was done on four different shapes, Elliptical, Hexagonal, Oblong and lenticular, as indicated in table 1. Experiments were conducted under clear-water conditions at different water discharges 13.89, 19.41, 23.77, 28.04 and 30.64 lit/sec and maximum depth of scour was measured. The test conditions for each shape of bridge piers are summarized in Table 1. 


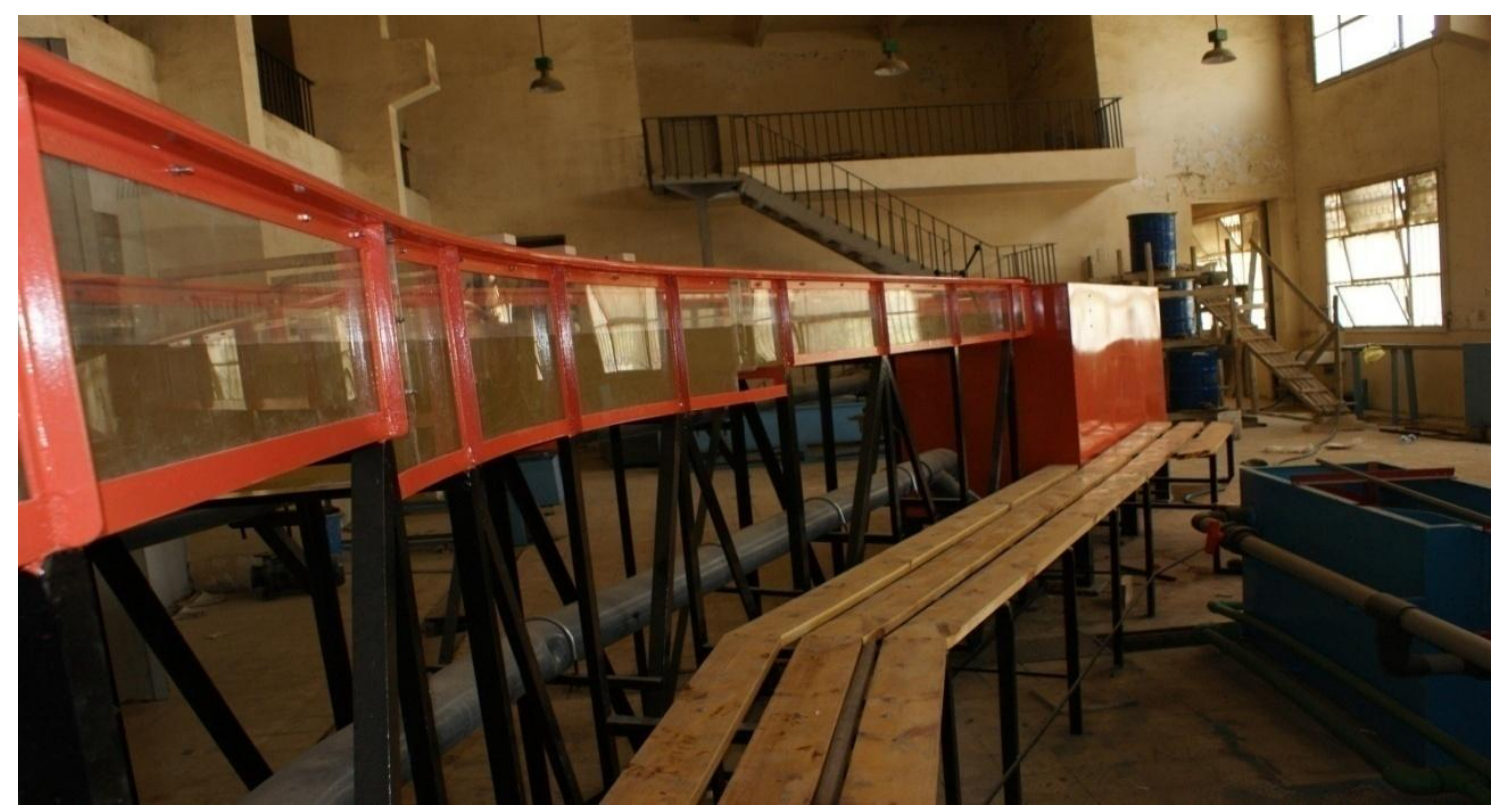

Photo: (1) General view of the experimental flume at Al- Azhar University.

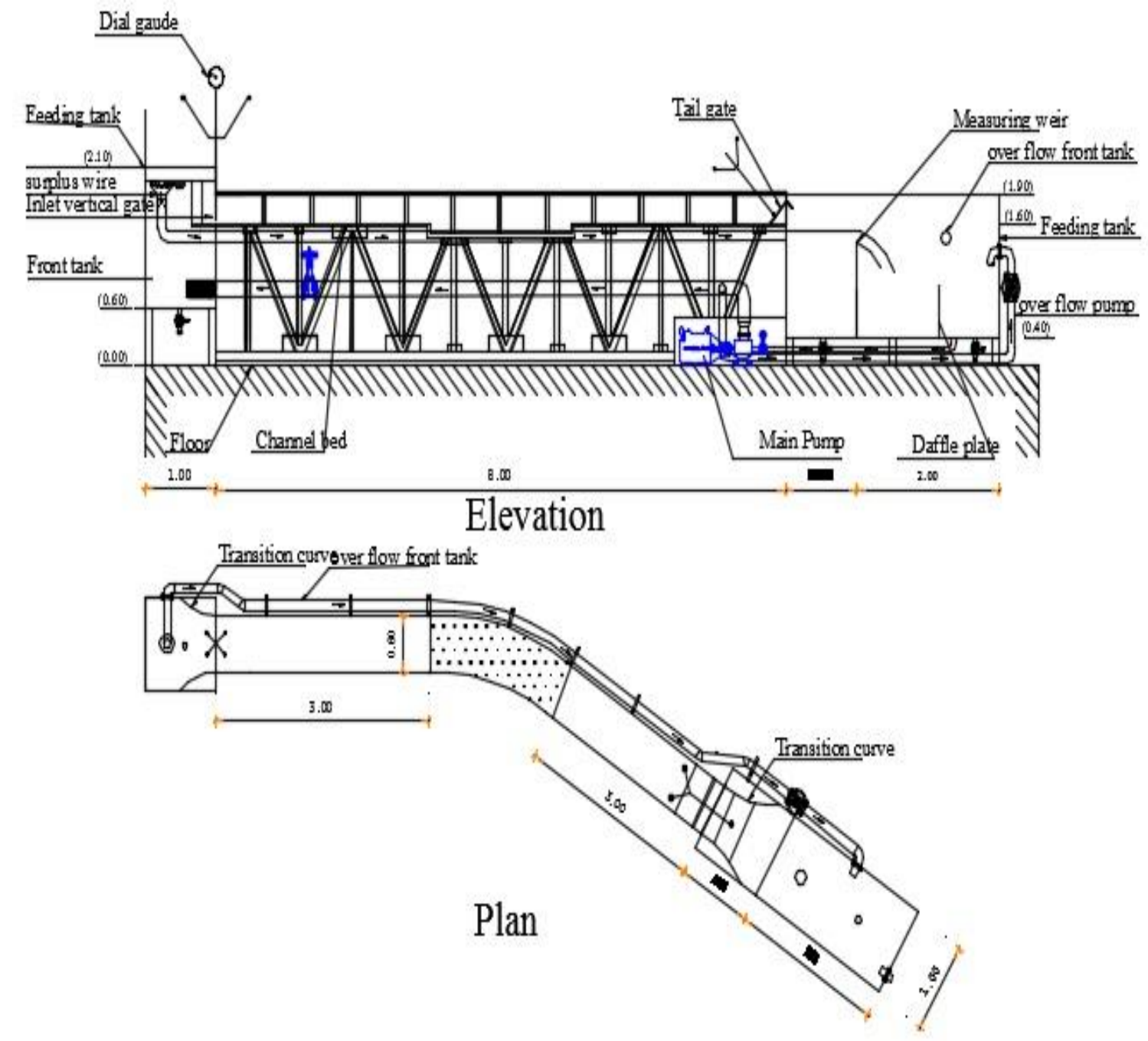

Sketch: (1) Experimental flume layout. 
INVESTIGATING SCOUR DEPTH AROUND BRIDGE PIERS IN CURVED CHANNELS

Table: (1) Test condition for test series

\begin{tabular}{|c|c|c|c|c|c|}
\hline NO & Shapes & $\mathrm{Y}(\mathrm{cm})$ & $\begin{array}{l}\text { Velocity in } \\
\text { channel } \mathrm{cm} / \mathrm{s}\end{array}$ & $\mathrm{Q}(\mathrm{L} / \mathrm{s})$ & $\mathrm{Fr}$ \\
\hline \multirow{5}{*}{$\mathrm{M}_{1}$} & \multirow{5}{*}{ Elliptical } & \multirow{5}{*}{13.5} & 17.15 & 13.89 & 0.15 \\
\hline & & & 23.93 & 19.41 & 0.21 \\
\hline & & & 29.34 & 23.77 & 0.25 \\
\hline & & & 34.62 & 28.4 & 0.3 \\
\hline & & & 37.83 & 30.64 & 0.33 \\
\hline \multirow{5}{*}{$\mathrm{M}_{2}$} & \multirow{5}{*}{ Hexagonal } & \multirow{5}{*}{13.5} & 17.15 & 13.89 & 0.15 \\
\hline & & & 23.93 & 19.41 & 0.21 \\
\hline & & & 29.34 & 23.77 & $\overline{0.25}$ \\
\hline & & & 34.62 & 28.4 & 0.3 \\
\hline & & & 37.83 & 30.64 & 0.33 \\
\hline \multirow{5}{*}{$\mathrm{M}_{3}$} & \multirow{5}{*}{ Oblong } & \multirow{5}{*}{13.5} & 17.15 & 13.89 & 0.15 \\
\hline & & & 23.93 & $\begin{array}{l}19.41 \\
\end{array}$ & $\overline{0.21}$ \\
\hline & & & 29.34 & 23.77 & 0.25 \\
\hline & & & 34.62 & 28.4 & 0.3 \\
\hline & & & 37.83 & 30.64 & 0.33 \\
\hline \multirow{5}{*}{$\mathrm{M}_{4}$} & \multirow{5}{*}{ Lenticular } & \multirow{5}{*}{13.5} & 17.15 & 13.89 & $\overline{0.15}$ \\
\hline & & & 23.93 & 19.41 & $\overline{0.21}$ \\
\hline & & & 29.34 & 23.77 & 0.25 \\
\hline & & & 34.62 & 28.4 & 0.3 \\
\hline & & & 37.83 & 30.64 & 0.33 \\
\hline
\end{tabular}

The models were placed at $\mathrm{b} / \mathrm{B}=0.5$ and at a tangential angle of zero. The bed material (sand) was accurately leveled and the leveling accuracy was checked by means of a water gauge and Ultrasonic meter; photo 2, The model is fitted at the assigned position. During the run, an ultrasonic device measured the water levels, depths and the scour depth. 


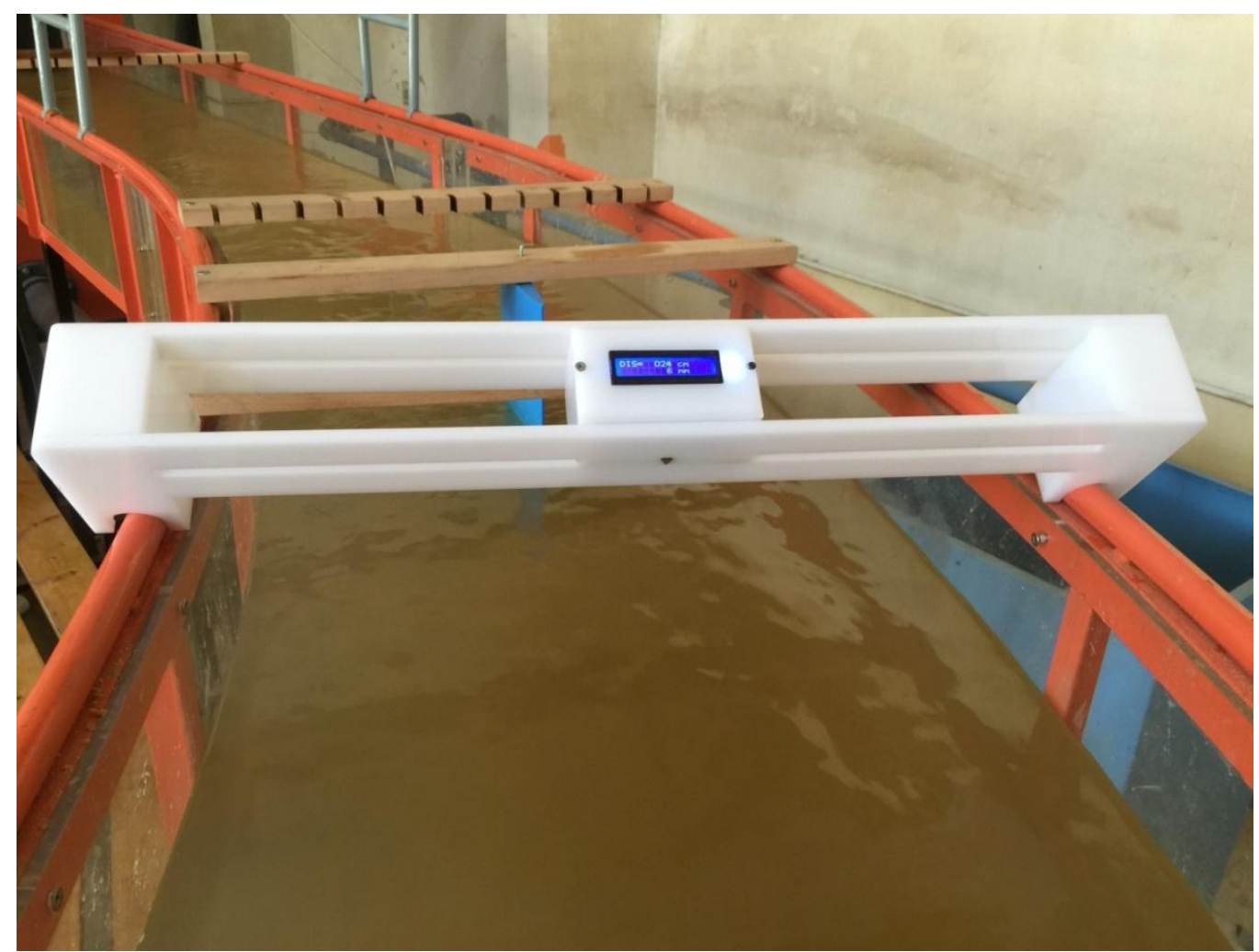

Photo: (2) Measuring device (Ultrasonic device - one spot).

\section{ANALYSIS}

Twenty (20) experiments were carried out; where angle was used at five (5) different discharges. Measurements were undertaken. Observations were recognized and photos were captured.

These measurements, observations and photos were documented and archived. They were analyzed, comprehended and plotted on graphs. These graphs are presented here. They are discussed with regard to the scour depth and time, as follows:

\subsection{SCOUR DEPTH RESULTS}

The relation between ds/dsm and Fr were documented and plotted, for all tested piers. Moreover, a regression analysis was carried out to correlate the two variables by means of polynomial equations in order to plot the best fitting curve.

Figures (2) to (6) present the relation between the relation between ds/dsm and Fr, from which, the following were observed:

- In general, ds is directly proportional to $\mathrm{F}_{\mathrm{r}}$.

- ds was found to be directly proportional to $\mathrm{F}_{\mathrm{r}}$.

- As for Elliptical pier $\left(\mathrm{M}_{1}\right)$, it contributed in the reduction of the scour depth ranged $18 \%$.

- For all the tested cases the appropriate pier shape is the Hexagonal shape $\left(\mathrm{M}_{2}\right)$ it contributed in the reduction of the scour depth in the range $34 \%$.

- Concerning the polygon (hexagonal shape $\left(\mathrm{M}_{3}\right)$, it contributed in the reduction of the scour depth by $27 \%$.

- Concerning the lenticular pier $\left(\mathrm{M}_{4}\right)$ it contributed in the reduction of the scour depth by $27 \%$.

- The concluded aspects are listed on table no (2). 


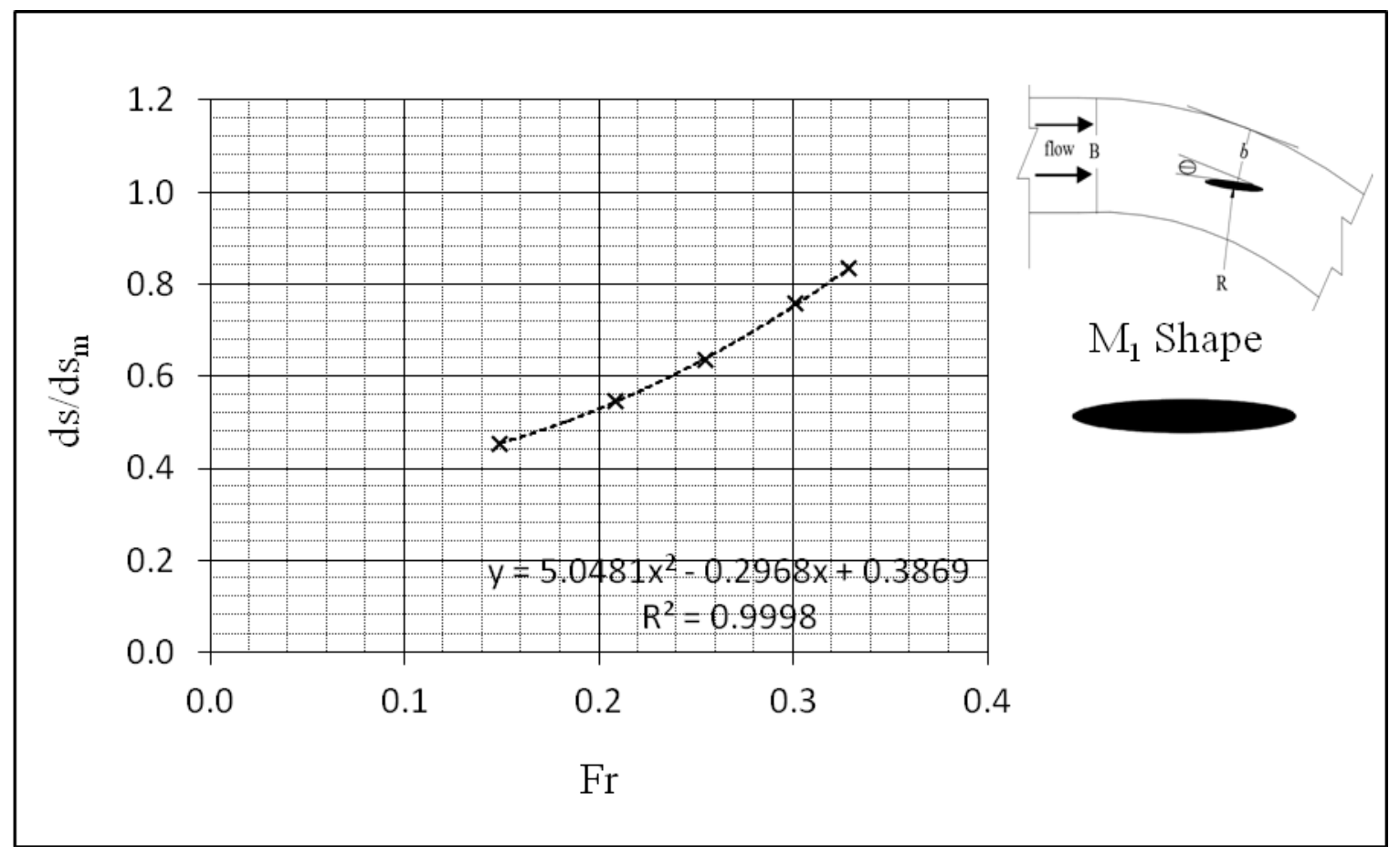

Figure: (2) The relation between $(\mathrm{Fr})$ and $\left(\mathrm{ds} / \mathrm{ds}_{\mathrm{m}}\right)$

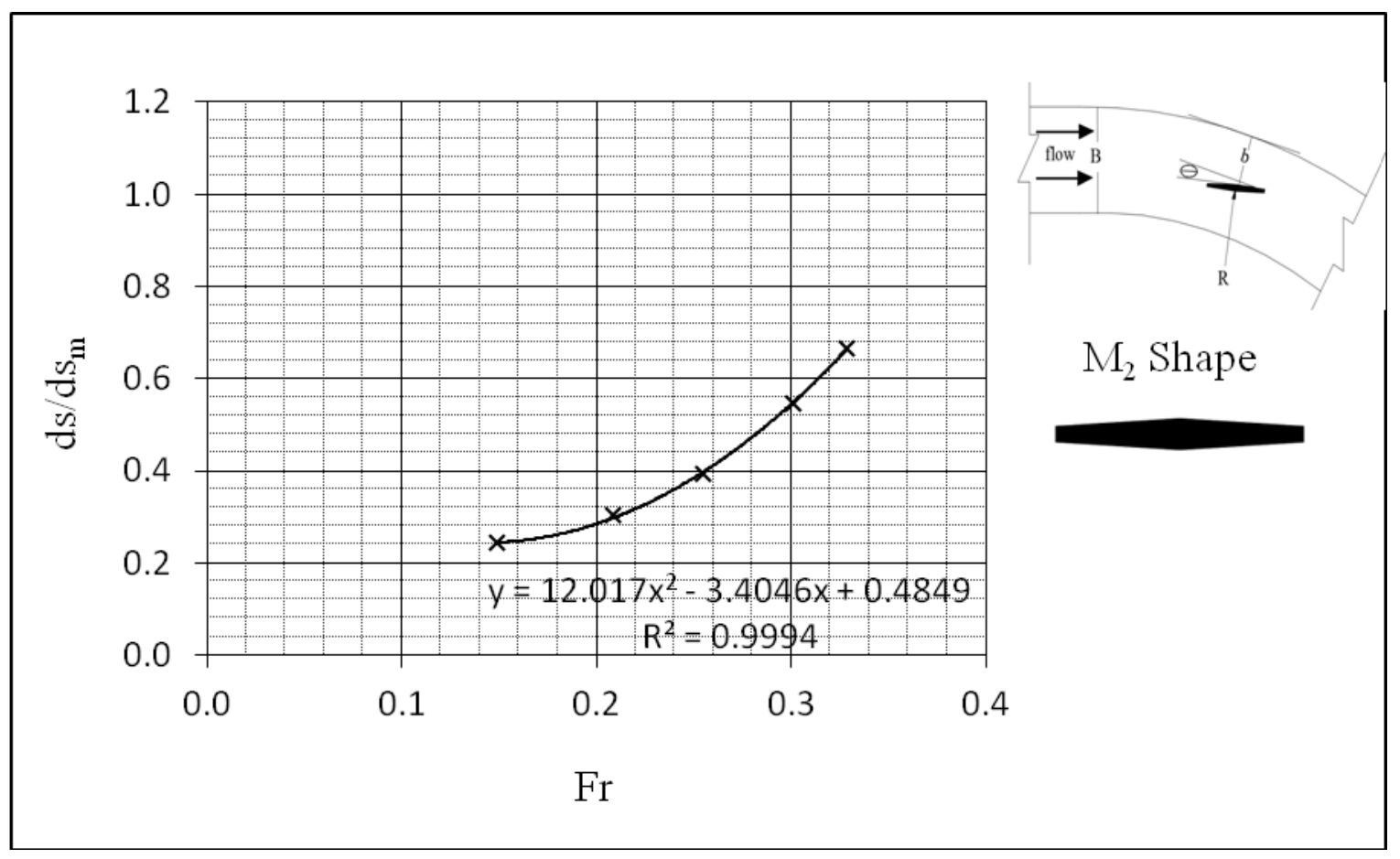

Figure (3): The relation between $(\mathrm{Fr})$ and $\left(\mathrm{ds} / \mathrm{ds} \mathrm{s}_{\mathrm{m}}\right)$ 


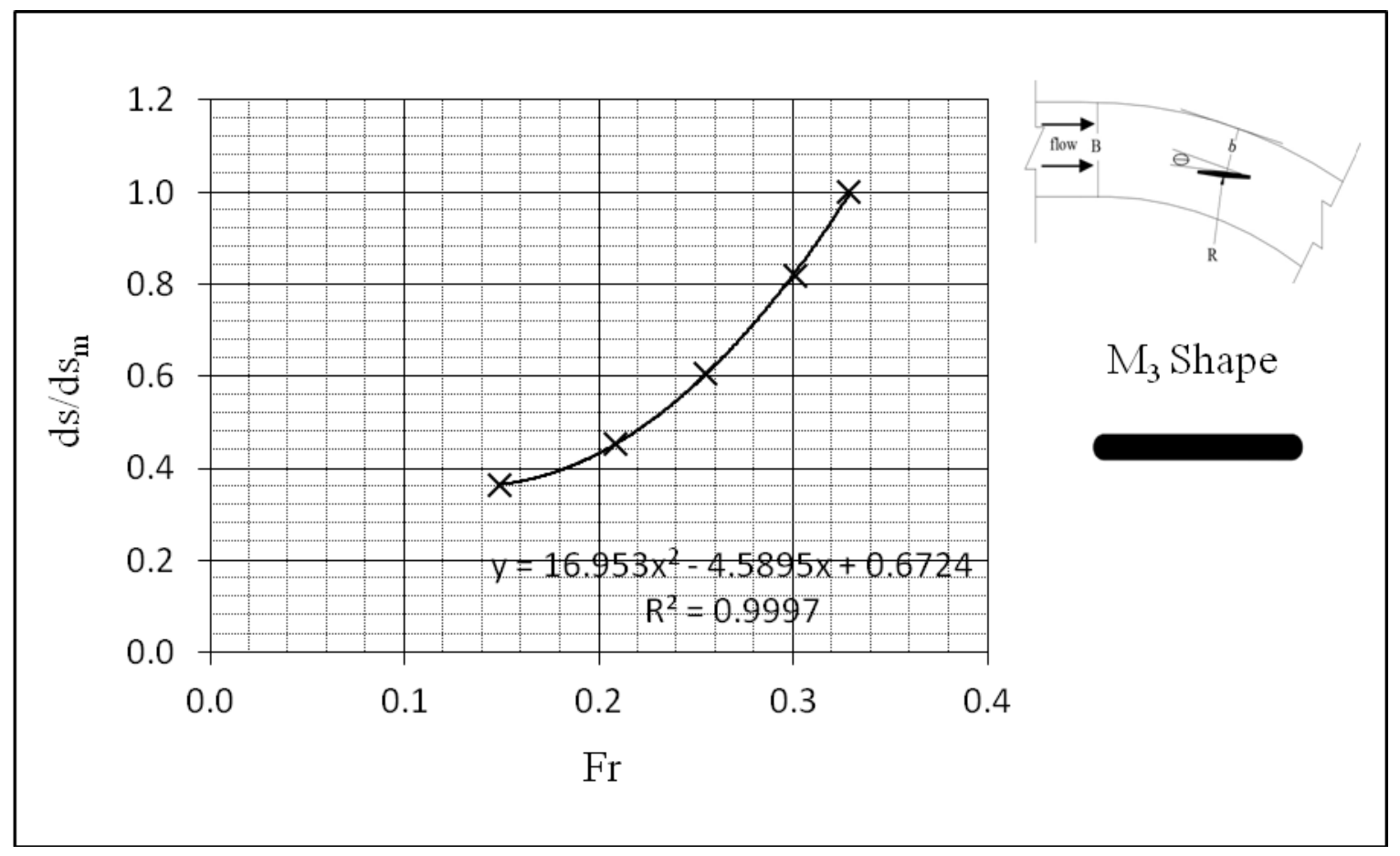

Figure: (4) The relation between $(\mathrm{Fr})$ and $\left(\mathrm{ds} / \mathrm{ds}_{\mathrm{m}}\right)$

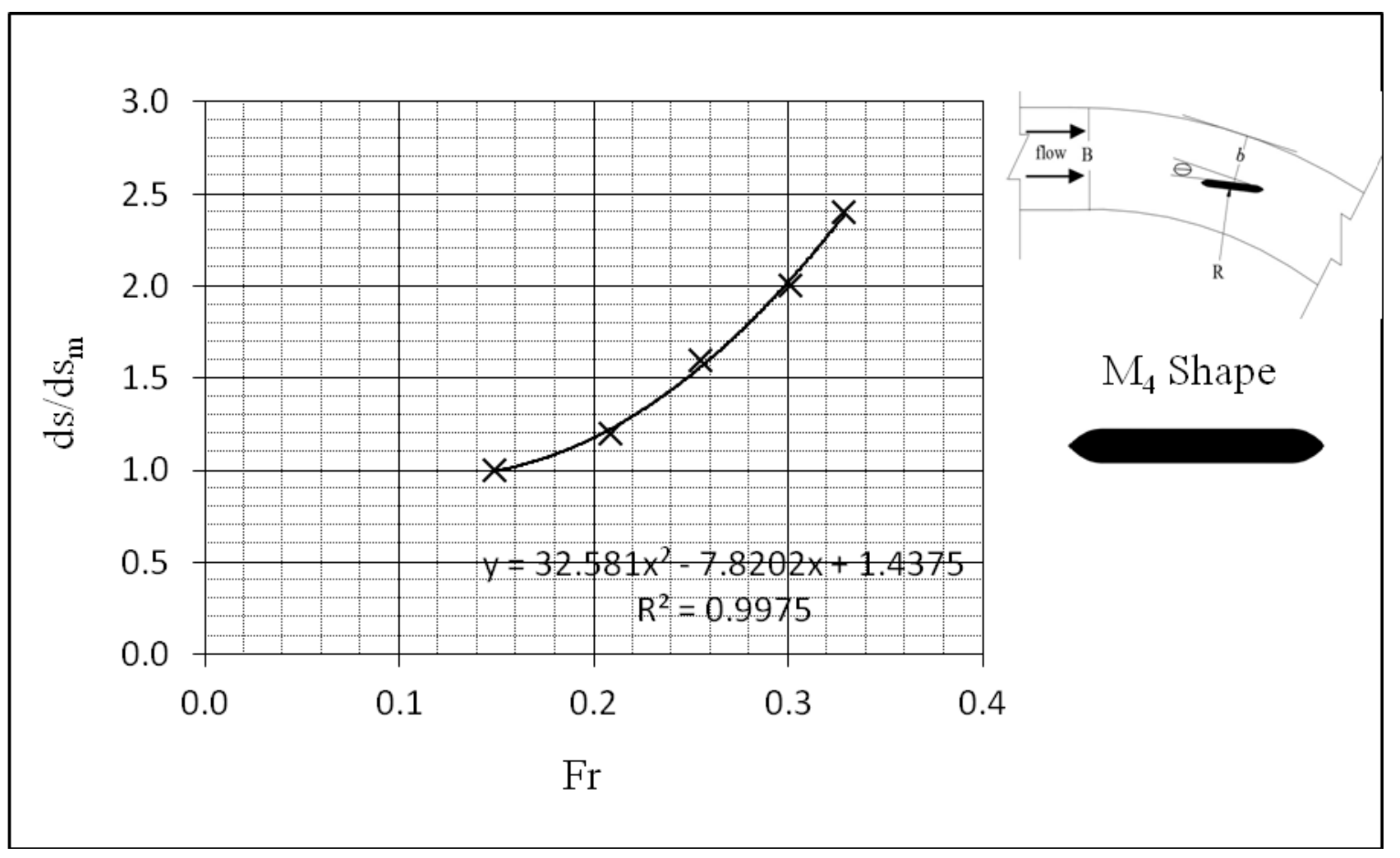

Figure: (5) The relation between $(\mathrm{Fr})$ and $\left(\mathrm{ds} / \mathrm{ds} \mathrm{s}_{\mathrm{m}}\right)$ 


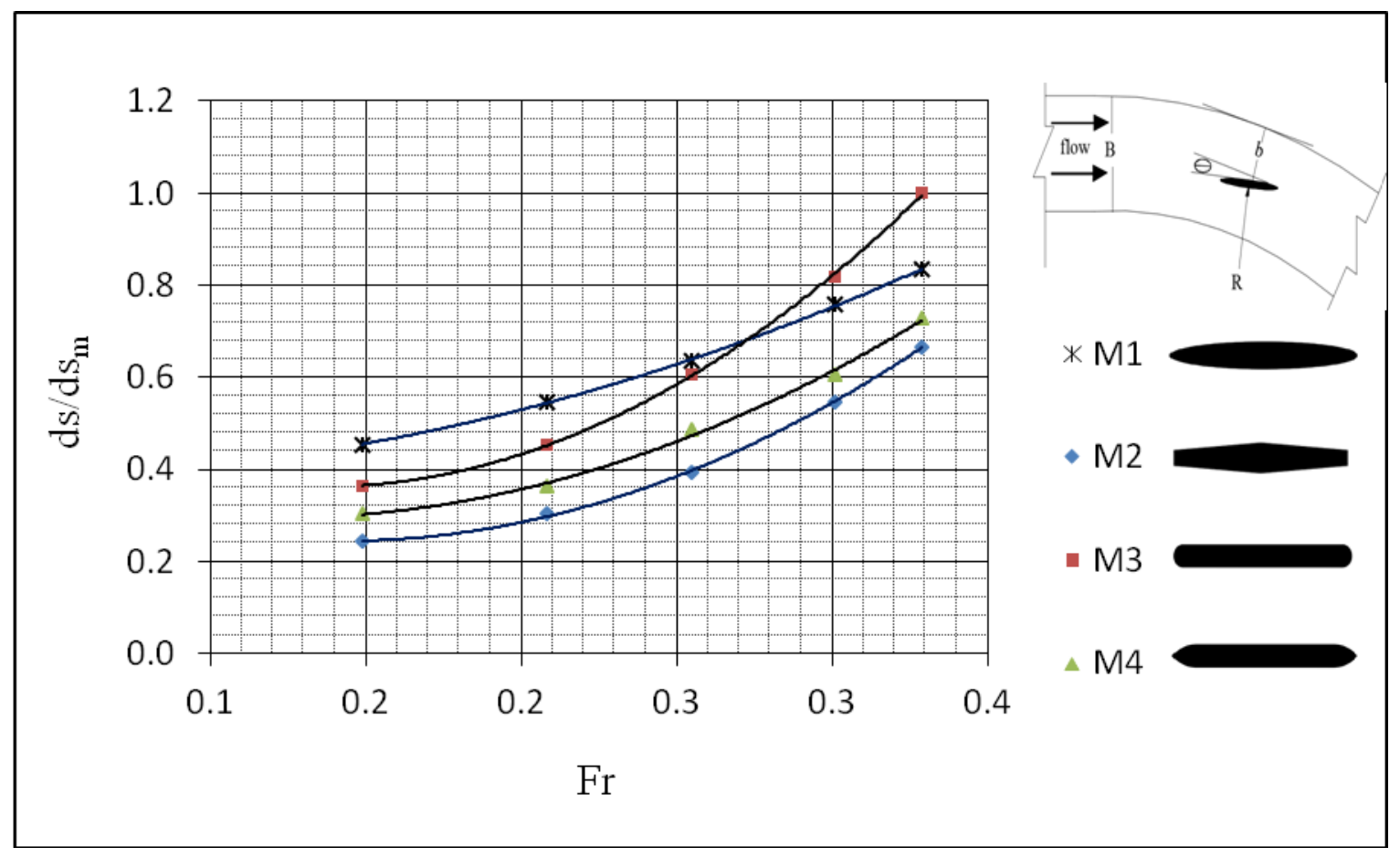

Figure: (6) The relation between (Fr) and (ds/ds $\left.s_{m}\right)$ for all shapes

Table (2) Pier shape effect

\begin{tabular}{|c||c||c||c||}
\hline shape & $\begin{array}{c}\text { Froude } \\
\text { number } \\
(-)\end{array}$ & $\begin{array}{c}\mathrm{ds} \\
(\mathrm{cm})\end{array}$ & $\begin{array}{l}\mathrm{ds} / \mathrm{dsm} \\
(\%)\end{array}$ \\
\hline \hline \multirow{2}{*}{$\mathrm{M}_{1}$} & 0.15 & 1.5 & 45 \\
\cline { 2 - 4 } & 0.33 & 2.75 & 83 \\
\hline \hline \multirow{2}{*}{$\mathrm{M}_{2}$} & 0.15 & 0.8 & 24 \\
\cline { 2 - 4 } & 0.33 & 2.2 & 67 \\
\hline \hline \multirow{2}{*}{$\mathrm{M}_{3}$} & 0.15 & 1.2 & 36 \\
\hline \hline \multirow{2}{*}{$\mathrm{M}_{4}$} & 0.33 & 3.3 & 100 \\
\hline
\end{tabular}

\subsection{RATE OF SCOUR DEPTH CHANGES}

The rates of scour depth changes were determined. The relations between ds/dsm and $\mathrm{T} / \mathrm{T}_{\mathrm{O}}$ were correlated. A regression analysis was executed to determine the best fitting curves to which logarithmic functions equations were derived, equations (1) to (4).

$$
\frac{d s}{d s_{m}}=0.11 \operatorname{Ln}\left(\frac{T}{T o}\right)+0.85 \text { For } \quad \mathrm{M}_{1,} \quad \text { Fr } \quad=\quad 0.33
$$

$$
\frac{d s}{d s_{m}}=0.091 \operatorname{Ln}\left(\frac{T}{T o}\right)+0.668 \quad \text { For } \mathrm{M}_{2}, \mathrm{Fr}=0.33
$$




$$
\begin{aligned}
\frac{d s}{d s_{m}}=0.138 \operatorname{Ln}\left(\frac{T}{T o}\right)+1.027 & \text { For } \mathrm{M}_{3}, \mathrm{Fr}=0.33 \\
\frac{d s}{d s_{m}}=0.07 \operatorname{Ln}\left(\frac{T}{T o}\right)+0.721 & \text { ForM }_{4}, \mathrm{Fr}=0.33 \\
& \text { Moreover, figures }
\end{aligned}
$$

Moreover, figures (7) to (11) were plotted to present the relation between $\mathrm{ds} / \mathrm{dsm}$ and $\mathrm{T} / \mathrm{T}_{\mathrm{O}}$, from which, it was observed that the value of relative scour depth $\left(\mathrm{ds}_{\mathrm{d}} / \mathrm{ds}_{\mathrm{m}}\right)$ increases by time.

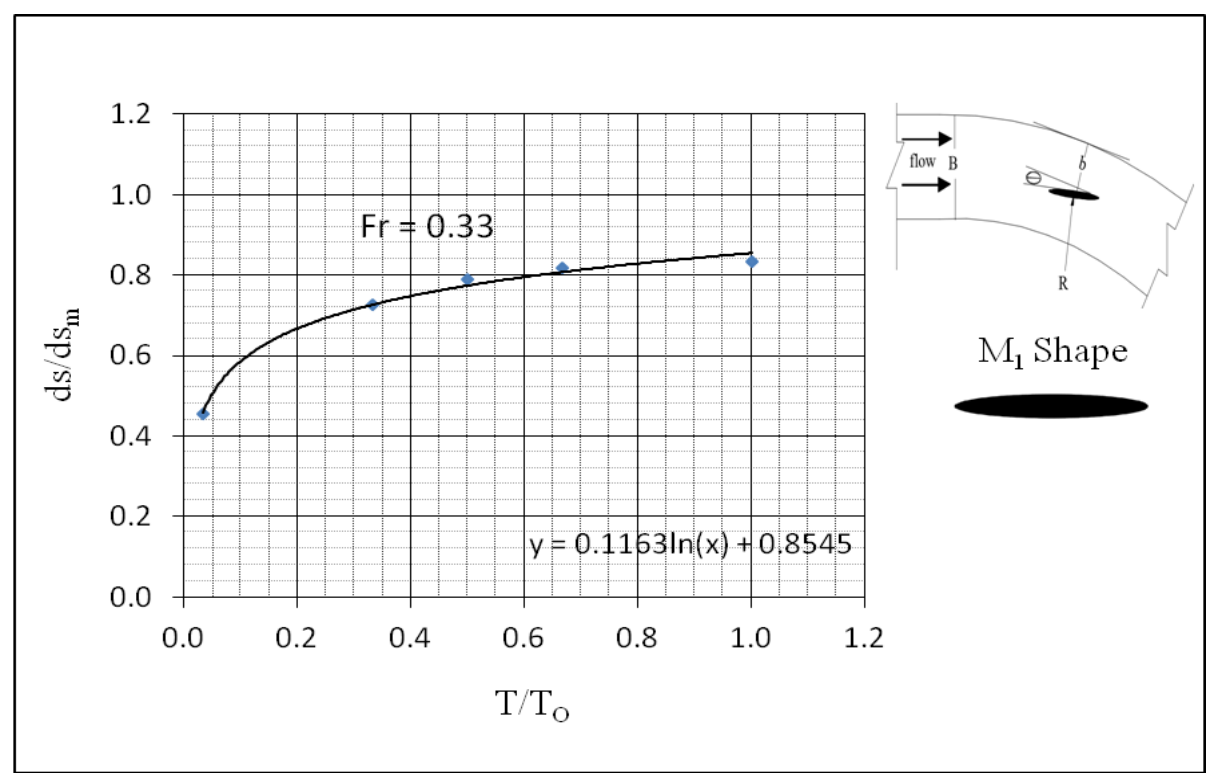

Figure: (7) The relation between $\left(T / T_{0}\right)$ and $\left(\mathbf{d s} / \mathbf{d s}_{\mathbf{m}}\right)$

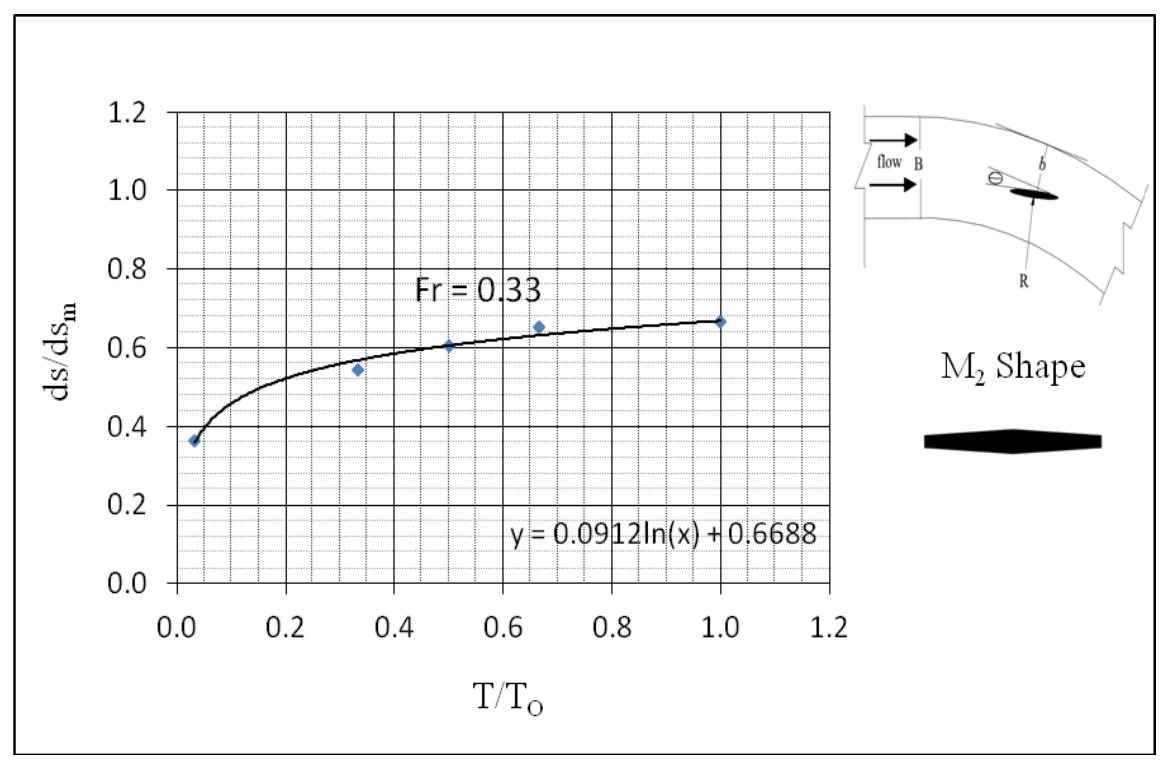

Figure (8): The relation between (T/TO) and (ds/dsm) 


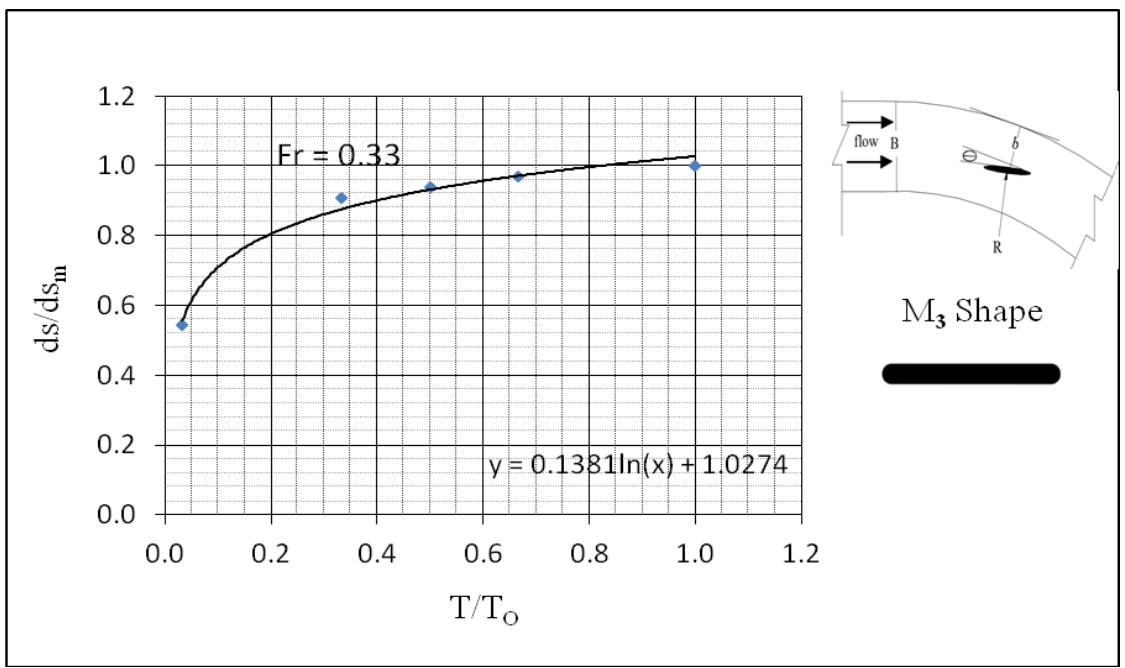

Figure (9): The relation between $\left(T / T_{0}\right)$ and $\left(d s / d s_{m}\right)$

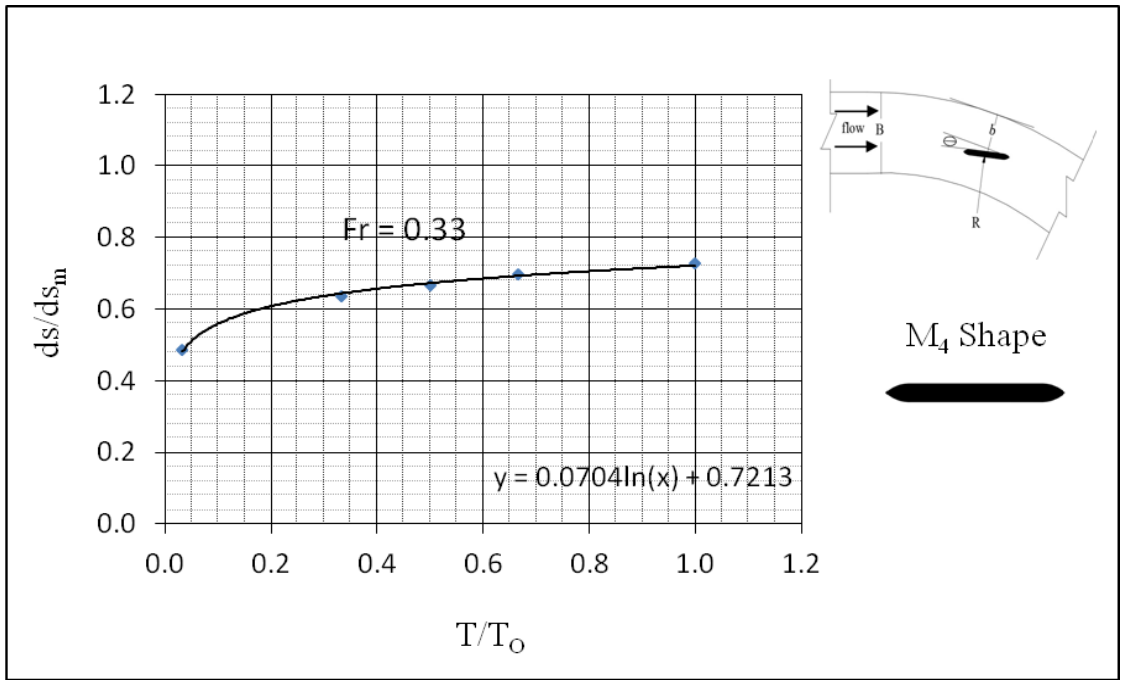

Figure: (10)The relation between $\left(\mathrm{T} / \mathrm{T}_{\mathrm{O}}\right)$ and $(\mathrm{ds} / \mathrm{dsm})$

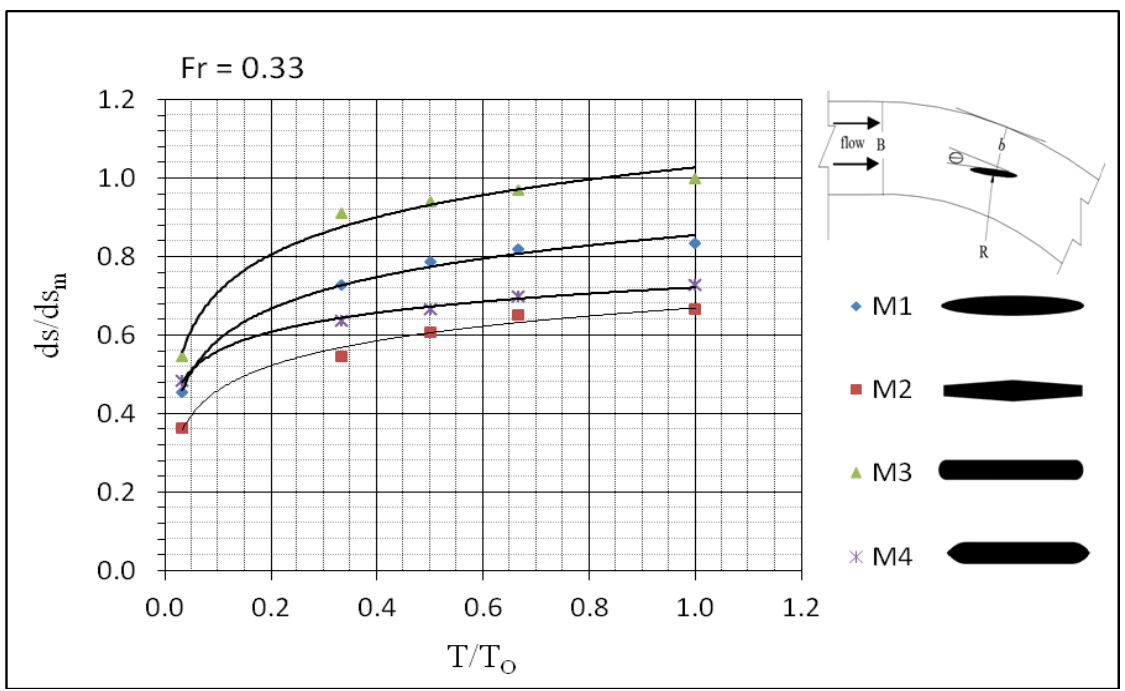

Figure: (11) The relation between $\left(T / T_{0}\right)$ and $\left(d s / d s_{m}\right)$ for all shapes 


\section{CONCLUSIONS}

Based on the above investigations, the conclusions are as follows:

- Piers are to be placed in curved channels with precautions

- The Polygon (hexagonal) piers are capable of reducing the scour depth, reasonably for the inclination angle to the tangent is equal to zero by $34 \%$ from maximum depth of scour.

- The elliptical shape was not effective at deceasing the depth of Scour

\section{REFERENCES}

1. A.Azhari,S.F.Saghravani and B.A. Mohammad nezhad (2005), Scour around a Bridge Pier, The Florida State University, Electronic Theses, Treatises and Dissertations The Graduate School, 10-28-2005, XVIII International Conference on Water Resources, CMWR 2010.

2. Abdul_Hassan .alShukur (2016) Experimental study of bridge pier shape to local scour vol. 7 Issue Feb 2016.

3. Ahmed, F. \&Rajaratnam, N. (1998). "Flow around bridge piers, Journal of Hyd. Engrg. ASCE, Vol. 124 No. 3, 288-300.

4. Ali Khodabakhshi, MojtabaSaneie, AbdolnabiAbdohKolahchi (2014), Study on Effect of Slot Level on Local Scour around Bridge Pier, IJRET: International Journal of Research in Engineering and Technology, Volume: 03, Feb-2014.

5. Arunachalam, K. (1965). Scour around bridge piers, Journal of Indian Roads Congr. 29 No.2, 189-207

6. Azamathulla, H., Ghani, A., Zakaria, N., and Guven, A. (2010) "Predict Bridge Pier Scour" Journal of Hydraulics (2010).

7. Baker, C.J. (1981). New design equation for scour around bridge piers, Journal of Hydraulic Division, A.S.C.E., Vol. 107 HY-4.

8. Breusers, H.N.C. \&Raudkivi, A.J. (1991). Scouring, Hydraulic Structure, Manual, I.A.H.R., Balkema, Rotterdam, Netherlands

9. Breusers, H.N.C. (1972).Local scour near offshore structures, Delft Hydraulics Laboratory, Publication No. 105.

10. Breusers, H.N.C., Nicollet, G. and Shen, H.W. (1977) "Local Scour Around Cylindrical piers." Journal of Hydraulic Research, 15(3), 211-252.

11. Breusers, H.N.C., Nicollet, G., \& Shen, H.W. (1977).Local scour around cylindrical piers, Journal of Hydraulic Research, Vol. 15 No, 211-252.

12. Chabert, J. \&Engeldinger, P. (1956). Etude des Affouillementautour des Piles des ponts (Study on scour around bridge Piers), Laboratoire National d'Hydraulique, Chatou, France.

13. Chiew, Y.M. \& Melville, B.M. (1987).Local scour around piers, Journal of Hydraulic Research, Vol. 25 No. 1, 15-26.

14. Chin-Lien Yen, Jihn-Sung Lai and Wen-Yi Chang (2001), Modeling of 3D Flow and Scouring around Circular Piers, Proc. Natl. Sci. Counc.ROC(A), Vol. 25, No. 1, 2001. pp. 17-26

15. Mohd.Sarfaraz (2011) Migration Characteristics of Meandering Channels Based on River Morphodynamics, European Science Foundation Conference, November 28 to December 1, 2011, SantFeliu de Guixols, Spain.

16. Mubeen Beg (2013) "Predictive competence of Existing Bridge Pier Scour Depth Predictors", European International Journal of Science and Technology Vol. 2 No. 1 February 2013.

17. YaserEmami, S. Amin Salamatian And Masoud Ghodsian (2008), Scour at Cylindrical Bridge Pier in A 180 Degree Channel Bend, Fourth International Conference on Scour and Erosion 2008. 